\title{
Hazing and Organizational Tradition in a Higher Education Institution in the Philippines: What Has the Law Got to Do with It?
}

\author{
Ofelia M. Bawan', Marilou P. Pascual2, Arneil G. Gabriel ${ }^{3}$ \\ ${ }^{1}$ College of Architecture, Nueva Ecija University of Science and Technology, Cabanatuan City, Philippines \\ ${ }^{2}$ College of Management and Business Technology, Nueva Ecija University of Science and Technology, Cabanatuan City, Philippines \\ ${ }^{3}$ Department of Public Administration, Nueva Ecija University of Science and Technology, Cabanatuan City, Philippines \\ Email: opats14@yahoo.com
}

How to cite this paper: Bawan, O.M., Pascual, M.P. and Gabriel, A.G. (2017) Hazing and Organizational Tradition in a Higher Education Institution in the Philippines: What Has the Law Got to Do with It? Open Journal of Social Sciences, 5, 110-125. https://doi.org/10.4236/jss.2017.512009

Received: November 18, 2017 Accepted: December 16, 2017 Published: December 19, 2017

Copyright $\odot 2017$ by authors and Scientific Research Publishing Inc. This work is licensed under the Creative Commons Attribution International License (CC BY 4.0).

http://creativecommons.org/licenses/by/4.0/

\begin{abstract}
The evolution of law started from human practice and activities. Many State laws are once part of society's living tradition ripened into a rule of conduct in the form of statute. The study argued that hazing is a tradition within student organizations. The implementation of the Anti-Hazing Law (RA8049) in the Philippines cannot fully stop this activity. Using the lens of 160 Sophomore student leaders, the study measured students' awareness on the existence of Republic Act 8049 also known as the Anti-Hazing Law. The study found that Majority of the Sophomore Engineering students: a) Possessed above average level of awareness on the nature of hazing as defined under RA 8049; b) "awareness" on the procedural requirements of RA 8049; and c) above average "awareness" on the liabilities imposed by law. The study concluded that despite knowledge of the law on anti hazing, the problem remains. The respondents' regard to initiation ritual as part of organizational tradition makes the practice of hazing difficult to combat. A Comprehensive Anti-Hazing campaign guided by the principle of restorative justice to promote organizational learning is recommended.
\end{abstract}

\section{Keywords}

Hazing, Student Awareness, Organization Tradition, Student Affairs and Development

\section{Introduction}

Hazing is commonly understood as the infliction of physical, social, psychological harm upon the person of an applicant to student organization or group as a 
prerequisite for admission. It is done as part of a ritual that people (such as college students) must go through before they are allowed to become members of a group [1]. If it is part of organizational tradition, how can one delineate that it is illegal? Living tradition is one social norm embraced by people and members of the same group. They know and observe tradition independently of its nature. A tradition is almost always judged by people observing it as right. If hazing is judged by students as organization ritual and actual adherence is made therefore, then hazing for them is not illegal but instead a duty of every student organization member. If it is regarded as a tradition, how can the law prevent hazing activities? The 14th Congress of the Philippines defined hazing as "an initiation rite or practice as a prerequisite for admission into membership in a fraternity, sorority or organization by placing the recruit, neophyte or applicant in some embarrassing or humiliating situations such as forcing him/her to do menial, silly, foolish and similar tasks or activities or otherwise subjecting him/her to physical or psychological suffering or injury".

There are various perceptions on hazing. Some scholars consider hazing as [2] negatively affecting student self esteem while Cornell University, and Penn State University, associated alcohol consumption to it. It is also considered as a means to consolidate Greek societies and prevent the entrance of "free riders" [3]. It is a mechanism of screening the applicant and integrating him to the group. Hazing has also the effect of limiting the diversity of relationship a member may establish during his collegiate years [4]. It is a test of masculinity cultivating loyalty and trust to the organization.

Many scholars asserted that hazing is now part of the culture of higher education and has become a serious concern of administrators and authorities. Administrative responses to hazing have been recorded since 1870 [5]. Not only because it occurs within the school campus [6] but also of its innumerable negative effects on the good image of learning institutions and personality of student-victims. Some school administrators in the Philippines have made a bold move of imposing moratorium on recognition of fraternities and sororities in school campuses while 44 American states have declared hazing as a crime [7]. In a study conducted in 2016, it was shown that laxity in the implementation of law and inadequate monitoring of student organizations and activities contributed to the proliferation of hazing activities [8]. The lack of common understanding on the issue among school administrators [9] has made the phenomenon difficult to prevent. Consequently, school administrators opted to classify hazing activities. They prohibit some while maintaining some [10]. The inadequate information and knowledge of the school administrators on hazing lessens the institutions capability to device an effective anti-hazing prevention program [11]. Thus, school administrators in Midwestern high school in the US, recommended that restorative justice based on Senge's five principles of organizational learning is practically and theoretically relevant to prevent hazing. 


\subsection{Theoretical/Legal Framework of Hazing in the Philippines}

The doctrine of parens patriae and the international commitment to uphold the rights of students against all forms of harm imposes upon the state the duty to act as guardian of the rights of the disadvantaged and underprivileged. The students are considered by law as belonging to the disadvantaged and weak sector. The State as "parent of the people" is duty bound to ensure that enjoyment of rights of students is observed in school campuses [12] subject only to the exercise of the regulatory power of the State to promote welfare of its citizens [13]. Through the implementation of RA 8049 [14] the duty is performed. Furthermore, the International Human Rights Law (IHRL) pronounces that the Philippines, as a state signatory and member of the United Nations (UN), must at all times, prevent human rights violations such as torture, cruel, inhuman or degrading punishment. The same covenant further requires the signatory State to respect the inherent right to life of every person. As a response to the covenant, signatory states passed upon statutes intended to secure every person's right to life. This imposes upon the school system the duty to protect its students.

The 1987 Philippine Constitution for instance, declares its resolve of respecting the dignity of human person, promote and protect respect for human rights [15]. Similarly, it pronounces that educational institution should promote physical, intellectual and social well being of the youth, the youth being crucial to nation building [16]. In view of this mandate, learning institutions are obliged by law to protect peace, safety and security of the students. It starts from the time when the school takes custody of the students. Accordingly, the Civil Code of the Philippines proclaims that such loco parentis role of teachers and school administrators over the person of the students cannot be delegated [17]. In other words, teachers and school administrators are liable for the tortuous acts committed by students in school while performing its function as instrumentality of the State and as substitute parents to students [18]. This legal framework made prevention of hazing in campus a duty of the government to its students. The failure of RA 8049 to deter commission of hazing affects the operation of HEI not only in the promotion of the holistic development of student in an atmosphere of peace and safety but also to realize its mandate [19] as the bastion of learning opportunities, leadership skills and development of students personality through a well planned student, academic cocurricular and extracurricular activities [20]. The noble mandate of the learning institution is now challenged by the problem of campus violence committed by student organizations specially Greek-letter organizations [21]. More than ever, the situation calls for an efficient student affairs professionals and student services that provides strict monitoring of student activities [22]. Otherwise, the legal and social mandate of learning institutions would remain an illusion negating to a certain extent the very purpose of learning institution [23] and of student organizations in school campus. 


\subsection{Objectives of the Study}

The implementation of RA 8049 also known as Anti-Hazing Law did not discourage commission of hazing activities in the Philippines [24]. From the year 2000 to present, there are 28 recorded deaths due to hazing. The number represents only those that reached the Court of Justice. Despite its importance, there is a gap in knowledge regarding the problem. Only a handful of researches have been written. There are reasons cited why hazing research is limited, to wit: a) the sensitivity of the issue as it involves legal controversy; b) the prevailing culture of silence (Code of Silence) among members of student organizations effectively preventing scientific inquiry to prosper, and c) the culture of" machismo" prevailing in Philippine society where hazing is seen as a practice associated to organization tradition and masculinity [4]. Thus, a question may be asked, where does the problem lie? Is it in the insufficient monitoring of student activities or the insufficient knowledge of members of student organizations on RA 8049? Or better yet, on the perception that hazing is a tradition within the organization? Apropos, what has the law got to do with it?

The study is intended to provide local literature on the "phenomenon" [25]. It is significant because it has the direct effect on the "lived experiences of students in campus". Results may be investigated and compared to some other contexts having similar organizational experiences. The general objective of the study is to measure the level of awareness of Sophomore student leaders on the Anti-Hazing Law or RA 8049. The level of awareness of students to a certain extent may help contribute to the prevalence of the phenomenon. Through micro sociological analysis or the in depth investigation of the phenomenon taking place within a small group of individuals, insights and ideas on how hazing may be prevented could be unraveled. By applying the legal framework provided for under RA 8049, the level of awareness of the participants is measured which in turn could be used as basis for further improvement of the law and a starting point for a massive anti hazing campaign within school campuses.

Specifically, the study measured the participants awareness on:

1) The general concept of hazing as defined by RA 8049;

2) the requisites for the application of RA 8049;

3) liabilities attached to violation;

4) and the implication of the findings to the efficacy of the anti hazing law.

\section{Methodology}

\subsection{Research Paradigm}

In a nutshell, the study is described by paradigm below, to wit; the paper follows the process presented above. It used the Anti-Hazing Law itself as the framework for evaluating the awareness of 160 sophomore student leaders on the pertinent provisions of RA 8049. Their understanding is measured through a set of survey questionnaires based on the important sections of the law itself. The responses are reinforced by reading related literature and focus group discussion. They are 
collectively considered by the study as the Inputs. As Figure 1 shows, the study is processed by measuring their specific awareness of the provisions of RA 8049 namely: a) basic understanding; b) procedural requirements of the law; c) liabilities imposed. The data gathered are given meanings and insights by means the application of statistical tools for analysis and analysis of related literature to come up with the findings. The entire process of interpretation of data is guided by the micro-sociological and legal frameworks that hazing is a function of ineffective implementation and involves small group norms which may ripen into traditional practice within the organization. The Outputs is a research study showing that hazing is already a part of student organization's internal interaction and processes that hinder effective implementation of RA 8049. The output may also serve as basis for recommendation. Such recommendations eventually form part of feedback or new inputs which may serve as basis for the revision or amendments of RA 8049 by the Philippine Congress. The entire process does not only provide insights on hazing as an organizational tradition but also may serve as basis for hazing intervention on and off school premises and may also set the trajectory of future hazing study.

\subsection{Participants}

The participants to the study are Second Year Engineering (herein after called the sophomore, during the school year 2012-2013. It consisted of 160 regular student leaders enrolled in the subject Political Science I. They are student leaders in the College of Engineering and are the common recruits/"victims" of recognized or even unrecognized student organizations. They are recruited

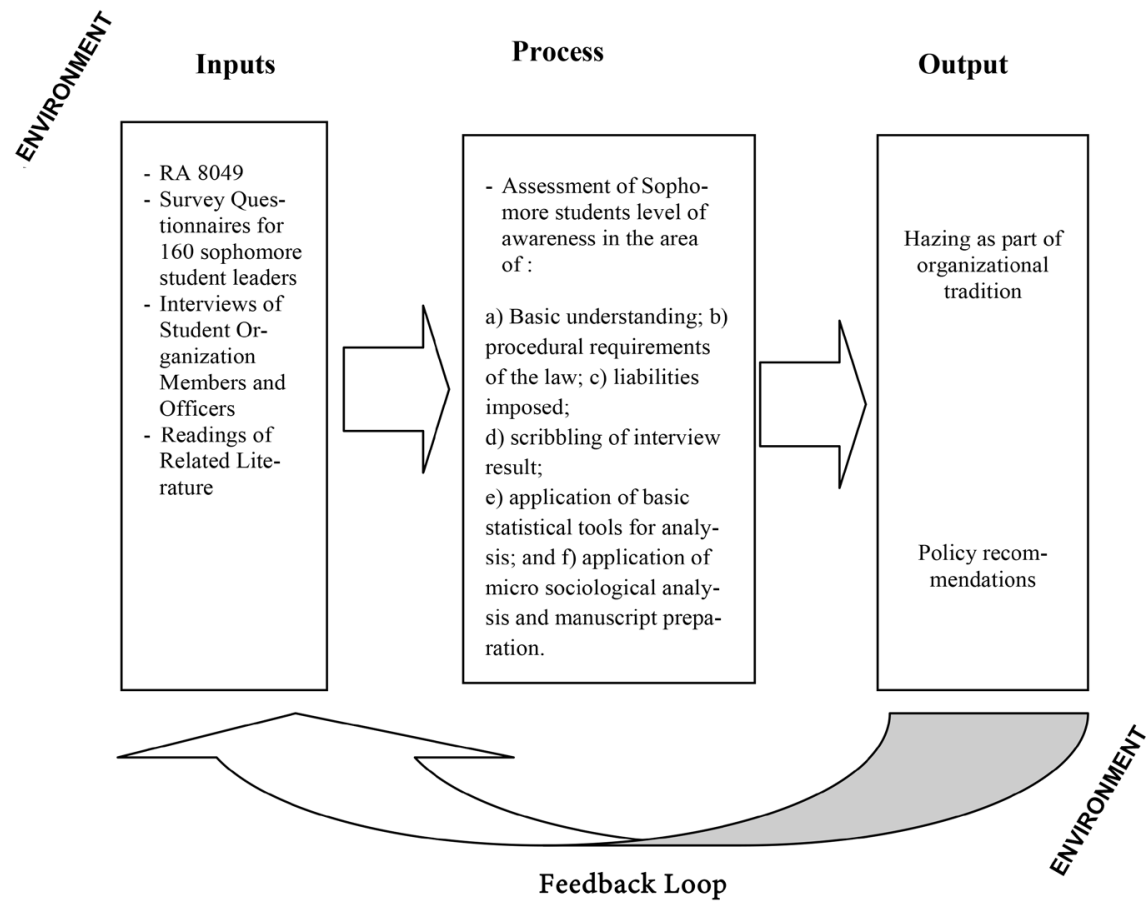

Figure 1. Systems model of policy analysis adopted from hill the policy process. 
because they are no longer covered by the prohibition set by the University Student Handbook against recruitment of Freshmen to student organizations. Secondly, the College of Engineering is one of a few male dominated colleges in the university having less than a thousand enrollees; Thirdly, the College of Engineering together with the College of Criminology are the most common target of student organizations (Greek letter societies) operating without proper university recognition.

\subsection{Research Instruments}

The instrument used to gather data is survey-questionnaire. The instruments are based on the Anti-Hazing Law (RA 8049). The validity of the questionnaires is determined by a legal practitioner holding cases related to violation of RA 8049. The survey questionnaire has three parts. The part on basic knowledge of the law; the procedural requirements for initiation ritual, and the liabilities imposed for violation. The responses were treated using percentile ranking and basic statistical tools. The instrument retrieval rate is ninety percent. Answers to the survey questionnaires are reinforced by focus group discussion. The general understanding of the participants of RA 8049 is measured using Likert Scaling technique. The weighted mean scales and verbal description are as follows:

Weighted Mean Verbal Description
1) $0-1.79$
Unaware
2) $80-2.59$
Moderately unaware
3) $60-3.39$
Aware
4) $40-4.19$
Moderately aware
5) $20-5.0$
Fully aware

\section{Results and Discussion}

\subsection{Demographic Profile}

Table 1 shows that majority or 63 percent of the respondents are eighteen years and above. They are of age of majority. Such finding is logical considering that they are sophomore students. On the other hand, Thirty six percent of the respondents are below eighteen years old. In legal parlance they are considered as children and therefore entitled to the statutory protection provided by RA 7610 or the Anti Child Abuse Law.

By legal implication, if physical, psychological or social humiliation is committed against them as a requirement for membership to student organization, the offenders shall be penalized under RA 8049 in relation to RA 7610. A stiffer penalty is therefore provided by law

However, as shown in Table 2, because of the demands of the labor market and the seeming equality of male and female in terms of intellectual capability, many women are now in the field of construction, plant maintenance operation and electric power generation. And many excel in their chosen field of specialization. 
Table1. Demographic profile as to the age of respondents.

\begin{tabular}{ccc}
\hline Age Range & Frequency & Percentage \\
\hline 17 and below & 59 & $36.8 \%$ \\
18and above & 101 & $63.2 \%$ \\
Total & 160 & $100 \%$ \\
\hline
\end{tabular}

Table 2. Profile as to gender.

\begin{tabular}{ccc}
\hline Gender & Frequency & Percentage \\
\hline Female & 62 & $38.75 \%$ \\
Male & 98 & $61.25 \%$ \\
Total & 160 & $100 \%$ \\
\hline
\end{tabular}

There are two types of student organizations in the university, one is the Non Political Student Organizations or NPSO for brevity and the other one is Political Student Organization or PSO for short. Table 3 presents the percentile distribution of organizational membership of the respondents. 100 percent are officers of PSO. Political organization consists of council, confederation, and the University Student Government (USG). By the rule of the university, an enrollee automatically belongs to a PSO based on his major field of specialization. They are all leaders of classes in the College of Engineering. Meanwhile, 22 percent of the respondents are at the same time officers of NPSO. This is so because, joining student interest groups like fraternity, religious, academic organizations and the like is optional. Only sophomore and older may join in the organization. Freshmen are temporarily restrained from joining student organization until they reach the age of majority.

\subsection{General Understanding of RA 8049}

Table 4 shows the responses of sophomore student leaders on the general understanding of the Anti-Hazing Law. A weighted mean of 4.35 or "fully aware", is shown when asked about the general description of hazing. 78 of the respondents or $48.75 \%$ are "fully aware" of the general description of hazing as related to infliction of physical harm. This has the legal implication that social and psychological harm do not fall under the definition of hazing. This could pose a greater risk for the respondents to be charged of hazing without the intention of violating the same. One must understand that RA 8049 is a special penal law thus, intent is immaterial to establish violation thereof [26].

Meanwhile, the respondents believe that hazing is present only in fraternity and sorority. As proven by catena of researches, acts of hazing are committed even by non-income generating student organizations like varsity team, and advanced military training [27]. Such awareness is contrary to the results of the study of Allan and Madden.

It is shown that a weighted mean of 3.58 represents the awareness on the concept of hazing as understood by the respondents as a phenomenon exclusive to 
Table 3. Demographic profile of respondents as to age membership in student organization $(\mathrm{N}=160)$.

\begin{tabular}{ccc}
\hline Membership in Organizations & Frequency & Percentage \\
\hline Political e.g. Student Council & 160 & $100 \%$ \\
Non Political e.g. Fraternity & 36 & $22 \%$ \\
\hline
\end{tabular}

fraternity and sorority. In this regard, the policy of preventing recognition of fraternities and sororities in campus to prevent hazing is supported by the respondents. Many of the respondents believe that it is an effective solution to the problem on hazing. A weighted mean of 3.35 is equivalent to "aware" description which in effect, accepting the idea that hazing prevention requires dissolution of Greek letter societies.

The policy on student organization is one of the means to prevent it. In this regard, a weighted mean score of 2.35 shows that the respondents are "moderately unaware" of the policy of the university on hazing. This finding is consistent with the observation that the university has no separate policy on hazing. What the university has is a general policy on violence and penalties for violation of Student Handbook provisions on attack against fellow students or another person. It is generally designated by the handbook as "oppression" (NEUST Handbook 2001). The rule however equates hazing and corporal punishment as prohibited act when used to select officers and members of the organization. This perhaps leads the students to believe that "hazing" is synonymous to corporal punishment excepting psychological and social humiliating experiences as part of the coverage of RA8049.

Alarming is the state of consciousness of the respondents of accepting the practice of hazing by reason of tradition. A weighted mean of 2.93 or "aware" shows the tendency of the participants of accepting hazing as a practice in the organization because it is a tradition. While the respondents are unaware that the purpose of the law is to regulate hazing and not intended to declare initiation ritual as illegal (RA8049). The practice of placing the recruits/neophytes/and applicants in a humiliating situation is seemingly acceptable to respondents especially when it is a part of group tradition. Placing the applicants in a humiliating situation is one aspect why hazing is prohibited. It demeans and degrades human person by virtue of his willingness to become member of an organization. It is one of the elements that makes the practice illegal hence, places itself under the coverage of RA 8049. The knowledge that is not clear to the respondents.

The common knowledge among students is that hazing connotes physical violence only. Social humiliation of the recruits is likewise an evil sought to be prevented by RA 8049 . The answer, "aware" reveals the respondents limited knowledge on the nature of hazing. Being aware that social humiliation is a must for a new entrant to the organization without interposing objection, is a sign that such a practice is acceptable to many. This is a wrong notion. The finding is consistent with the response on item question number one (1) where many believe 
that hazing involves only physical mishandling of recruits and not related to infliction of social or psychological suffering. Table 1 reveals that 78 of the respondents or close to 48 percent $(47.75 \%)$ of the total number of respondents are fully aware that hazing involves physical harm only. The low level of awareness on the nature of hazing is detrimental to prevent hazing incidence. They might break the law without mens rea.

The misconception that hazing is exclusive to fraternity and sorority is revealed on Table 4. At a glance, a total of 141 of the respondents held the idea that hazing is present only among fraternities and sororities. 88 percent (88\%) of the total responses are ranging from "fully aware" to "aware"; showing in effect that it is exclusive to Greek society. Majority or one hundred seven (107) are not informed of the exception provided by law. The PNP and AFP physical and

Table 4. Sophomore engineering students general understanding of RA 8049.

\begin{tabular}{|c|c|c|c|c|c|c|c|c|c|c|c|c|c|}
\hline \multirow{2}{*}{$\begin{array}{c}\text { PART II GENERAL } \\
\text { UNDERSTANDING } \\
\text { Questions/Items }\end{array}$} & \multicolumn{2}{|c|}{5 Fully aware } & \multicolumn{2}{|c|}{$\begin{array}{l}4 \text { Moderately } \\
\text { aware }\end{array}$} & \multicolumn{2}{|c|}{3 Aware } & \multicolumn{2}{|c|}{$\begin{array}{l}2 \text { Moderately } \\
\text { Unaware }\end{array}$} & \multicolumn{2}{|c|}{1 Unaware } & \multirow[b]{2}{*}{ TWF } & \multirow[b]{2}{*}{ WM } & \multirow[b]{2}{*}{ VD } \\
\hline & $\mathrm{f}$ & $\mathrm{TF}$ & $\mathrm{f}$ & $\mathrm{TF}$ & $\mathrm{f}$ & $\mathrm{TF}$ & $\mathrm{f}$ & $\mathrm{TF}$ & $\mathrm{f}$ & $\mathrm{TF}$ & & & \\
\hline $\begin{array}{l}\text { 1) Hazing is an act of inflicting } \\
\text { physical harm upon the person of } \\
\text { applicant to student organization } \\
\text { (Section 1) }\end{array}$ & 76 & 380 & 44 & 176 & 30 & 90 & 2 & 4 & 14 & 14 & 664 & 4.15 & Fully Aware \\
\hline $\begin{array}{l}\text { 2) Hazing takes place only in } \\
\text { fraternity and sorority. }\end{array}$ & 23 & 115 & 68 & 272 & 53 & 159 & 6 & 12 & 16 & 16 & 574 & 3.58 & Mod Aware \\
\hline $\begin{array}{l}\text { 3) Hazing is legal because it is part } \\
\text { of tradition. }\end{array}$ & 19 & 95 & 33 & 132 & 49 & 147 & 30 & 60 & 35 & 35 & 469 & 2.93 & Aware \\
\hline $\begin{array}{l}\text { 4) The university has a policy on } \\
\text { hazing }\end{array}$ & 13 & 65 & 15 & 60 & 45 & 135 & 30 & 60 & 57 & 57 & 482 & 2.35 & Mod Unaware \\
\hline $\begin{array}{l}\text { 5) To ban fraternity and sorority } \\
\text { also prevents hazing. }\end{array}$ & 30 & 150 & 41 & 164 & 54 & 162 & 17 & 34 & 23 & 23 & 536 & 3.35 & Aware \\
\hline $\begin{array}{l}\text { 6) The intention of RA } 8049 \text { is to } \\
\text { regulate initiation rites (Section } 1 \text { ). }\end{array}$ & 15 & 75 & 40 & 160 & 53 & 159 & 29 & 58 & 29 & 29 & 481 & 3.0 & Aware \\
\hline $\begin{array}{l}\text { 7) To embarrass/ridicule/recruit to } \\
\text { an organization is an acceptable } \\
\text { practice. (Section } 1 \text { ) }\end{array}$ & 17 & 85 & 34 & 136 & 55 & 165 & 32 & 64 & 25 & 25 & 476 & 2.97 & Aware \\
\hline $\begin{array}{l}\text { 8) Requiring the recruit to undergo } \\
\text { polish/ridiculous/degrading act is } \\
\text { acceptable and legal. }\end{array}$ & 22 & 110 & 42 & 168 & 42 & 126 & 44 & 88 & 22 & 22 & 514 & 3.2 & Aware \\
\hline $\begin{array}{l}\text { 9) Subjecting the recruit to physical } \\
\text { suffering is allowed by under RA } \\
8049 \text {. }\end{array}$ & 21 & 105 & 36 & 144 & 54 & 162 & 29 & 58 & 20 & 20 & 489 & 3.05 & Aware \\
\hline $\begin{array}{l}\text { 10) Psychological suffering is not } \\
\text { hazing. }\end{array}$ & 17 & 85 & 26 & 104 & 51 & 153 & 39 & 78 & 29 & 29 & 449 & 2.80 & Aware \\
\hline $\begin{array}{l}\text { 11) Psychological suffering is } \\
\text { merely a test of determination to } \\
\text { enter student-organization. }\end{array}$ & 25 & 125 & 37 & 148 & 49 & 147 & 28 & 56 & 27 & 27 & 503 & 3.14 & Aware \\
\hline $\begin{array}{l}\text { 12) Psychological and Physical } \\
\text { testing in the Police and military is } \\
\text { covered by RA } 8049 \text {. }\end{array}$ & 18 & 90 & 38 & 152 & 50 & 150 & 40 & 80 & 20 & 20 & 473 & 2.95 & Aware \\
\hline 13) Hazing is illegal per se. & 42 & 210 & 42 & 168 & 49 & 147 & 17 & 34 & 24 & 24 & 538 & 3.64 & $\begin{array}{l}\text { Moderately } \\
\text { aware }\end{array}$ \\
\hline $\begin{array}{l}\text { 14) Intoxication aggravates the } \\
\text { master's/initiator's liability. }\end{array}$ & 16 & 80 & 30 & 120 & 61 & 183 & 29 & 58 & 22 & 22 & 463 & 0.2 .89 & Aware \\
\hline
\end{tabular}


psychological testing are exempted from the coverage of RA 8049. A total of 67 percent $(67 \%)$ of the respondents are aware that the two government institutions are covered by RA 8049 when in truth straight provision of law provides otherwise (Section 1, subsection 3, RA 8049). This shows limited awareness of sophomore students on the coverage of the law. Finally, 132 of the respondents or close to 82 percent or (82.5\%) believe that hazing is illegal per se (Part II, item number 14, RA 8049). The finding again is a revelation of the limited awareness of the respondents on the true nature of RA 8049. It is intended only to regulate initiation ritual and prevent hazing and similar activities and not to prohibit it. It is a reflection of their wrong notion of the concept/nature of hazing. A general weighted average of 3.38 is arrived at verbally described as "moderately aware" status.

\subsection{Knowledge on Procedural Requirements}

The requirements of RA 8049 are enumerated in Table 5. It shows not only the level of awareness of sophomore students on the general concept of hazing but also the requirements which the law mandates to make initiation rites legal. There is a low level of awareness among the student respondents with regards to procedural and documentary requirements of the law intended to regulate the

Table 5. Knowledge on procedural requirements of RA 8049.

\begin{tabular}{|c|c|c|c|c|c|c|c|c|c|c|c|c|c|}
\hline & \multicolumn{2}{|c|}{5 Fully Aware } & \multicolumn{2}{|c|}{$\frac{4 \text { Moderately }}{\text { Aware }}$} & \multicolumn{2}{|c|}{$\underline{3 \text { Aware }}$} & \multicolumn{2}{|c|}{$\frac{2 \text { Moderately }}{\text { Unaware }}$} & \multicolumn{2}{|c|}{1 Unaware } & \multirow[b]{2}{*}{ TWF } & \multirow[b]{2}{*}{ WM } & \multirow[b]{2}{*}{ VD } \\
\hline & f & $\mathrm{TF}$ & $\mathrm{f}$ & $\mathrm{TF}$ & $\mathrm{F}$ & $\mathrm{TF}$ & f & $\mathrm{TF}$ & $\mathrm{f}$ & $\mathrm{TF}$ & & & \\
\hline \multicolumn{14}{|l|}{ Part III. Requirements of RA 8049} \\
\hline $\begin{array}{l}\text { 1) Any form of initiation rites are } \\
\text { prohibited by RA } 8049\end{array}$ & 20 & 100 & 30 & 120 & 50 & 150 & 33 & 66 & 33 & 33 & 469 & 2.93 & Aware \\
\hline $\begin{array}{l}\text { 2) Initiation rites can be a legal } \\
\text { practice of organization members }\end{array}$ & & & & & & & & & & & & & \\
\hline $\begin{array}{l}\text { provided that it observes the } \\
\text { requirements set by RA } 8049 \\
\text { (Section 2) }\end{array}$ & 19 & 95 & 36 & 144 & 57 & 171 & 28 & 56 & 26 & 26 & 466 & 2.91 & Aware \\
\hline $\begin{array}{l}\text { 3) RA } 8049 \text { requires that initiation } \\
\text { rites must be supported by a written } \\
\text { approval of the university authorities } \\
\text { (Section 3) }\end{array}$ & 26 & 130 & 36 & 144 & 55 & 165 & 23 & 46 & 26 & 26 & 511 & 3.18 & Aware \\
\hline $\begin{array}{l}\text { 4) Any initiation rites can be extended } \\
\text { for } 3 \text { or more days provided the }\end{array}$ & & & & & & & & & & & & & \\
\hline $\begin{array}{l}\text { university allows its holding and no } \\
\text { physical violence is inflicted upon the } \\
\text { neophyte/recruit/applicant (Section 3) }\end{array}$ & 23 & 115 & 32 & 128 & 58 & 174 & 33 & 66 & 30 & 30 & 513 & 3.21 & Aware \\
\hline $\begin{array}{l}\text { 5) Every time student organization } \\
\text { holds initiation rites names of recruits } \\
\text { must be known to the university } \\
\text { authorities. }\end{array}$ & 20 & 100 & 36 & 144 & 59 & 177 & 22 & 44 & 29 & 29 & 494 & 3.08 & Aware \\
\hline $\begin{array}{l}\text { 6) Calculated physical violence can be } \\
\text { employed during initiation rites } \\
\text { provided the recruits can physically } \\
\text { handle it. }\end{array}$ & 17 & 85 & 46 & 184 & 54 & 162 & 24 & 48 & 25 & 25 & 504 & 3.15 & Aware \\
\hline
\end{tabular}


holding of initiation rites and other similar activities. A weighted mean of 2.93 equivalent to a verbal description of "aware" tends to show their belief that RA8049 covers all forms of initiation rites. Indeed, all initiation rites must observe the regulatory measures set by RA 8049 , but it does not make illegal the holding of initiation rituals.

However, only those practices that are intended to inflict physical harm, social humiliation, and psychological suffering on the recruit/neophyte or applicant are prohibited. Hence if there is no requirement as to the aforementioned practices, it is not covered by law e.g. community outreach program. Table 5 also shows the students understanding on the duration when hazing may last. The weighted mean of 3.21 or "aware" reveals the student inadequate knowledge on the procedural requirement of RA 8049. Though, the same may be done, the law provides that it should not be more than three days. No extension of days is allowed. Further requirement is the knowledge of the school authorities of the activity. That such recognizance of school authorities cannot provide legal basis for extension of the duration initiation ritual. It is exactly the reason behind the law. It was found out that the longer the period of initiation ritual the greater the risk that initiators would manifest aggressive behavior. The same Table 5 shows the respondents awareness on the procedural intricacies of RA 8049. The names of recruits shall be written and known to the university authorities. A weighted mean of 3.08, or "aware" suggests that the same is known to them but is not enough to make them observe the same. As per the record of the university authorities no student organization has ever requested to hold initiation rites. Since there has been no request for the purpose, it follows that no list of names for initiation rites may have been submitted and requested for approval. It therefore shows the non observance of this procedural requirement. Furthermore it could have been the reaction of Greek societies on the moratorium for recognition imposed by the CHED. To operate outside of the ambit of university recognition. Monitoring therefore is difficult if not impossible.

The weighted mean of 3.15 or "aware" for question number 6, part III suggests that the respondents accept physical violence as part of organizational ritual. The response to the question interposes no objection to such practice. It seems that physical violence upon the person of a neophyte is right if it is calculated or when the physical stamina of the applicant could withstand physical pressure. This means that the more robust the applicant, the greater the degree of physical harm he may have to receive from the initiators. And for as long as physical pressure is dependent upon the physical built of neophytes, the same is, for the respondents, "reasonable". What is prohibited by law cannot be made legal under all circumstances. Physical violence upon the person of a neophyte is the very evil which RA 8049 sought to be prevented. Whether it is calculated or not, or the applicant could withstand the physical test or not, it remains illegal. This goes to show that respondents are not well informed of the reason for the passage of RA 8049.

Question number 1 of part III, provides for the students understanding that 
RA 8049 prohibits all forms of initiation rite. This reveals the students inadequate knowledge on the nature and purpose of RA 8049. As long as the activity observes the requirements set by law, it cannot be branded as illegal. What the law intends to achieve is to impose stricter monitoring and requirements before initiation ritual may take place. The law does not cover initiation rite designed not to inflict physical, social and psychological harm to applicant. It does not cover all initiation rites. Majority of the respondents are "aware" of the requirements of the law in making initiation rite legal and acceptable. That is when it complies with the procedural requisites of the university authorities or the law itself. The "aware" scale is dominant from question 1 up to question number 6. A weighted average of 3.07 on procedural awareness is arrived at verbally described as aware status.

\subsection{Knowledge on Liabilities}

Table 6 presents the measure of knowledge of sophomore students in so far as liabilities attached by law are concerned.

Table 6 presents the overall responses of sophomore leaders on the liabilities of offenders of RA 8049. It shows that respondents are not fully aware of the specific liabilities attached to every violation of the law. Observable is the finding on the higher level of awareness of the respondents on the need for awareness campaign (Question 10). A weighted mean of 3.98 or "moderately aware" tends to show the need for training and seminar on the subject and the related laws that cover hazing.

Generally, the respondents sophomore respond fairly high in the questions presented. They are relatively possessing higher level of awareness in terms of liabilities. It is not however, clear whether such knowledge on liabilities were derived from readings or by the sheer dictates of logic and general understanding that when there is a law violated somebody has to take the responsibility.

Inviting one's attention to question 8 , it is clear by a weighted mean of 3.16 or "aware" that respondents are placing the burden to social institutions to end hazing incidence. Such as the Department of Justice for prosecution; schools for awareness campaign and the Law Enforcement Agencies for proper implementation of RA 8049. They are directly responsible for the observance of its provisions. This finding is logical considering that it is the government who signed in the international covenant of promoting human rights and not the students. Hence, it is the government instrumentality that is duty bound to prevent hazing and protect students who are commonly treated as one of the vulnerable sectors. Section 2 of RA 8049 provides for the liability of members and officers in case death occurs during hazing. 42 of the respondents or $26.25 \%$ are "fully aware" that liability for the principal attaches, while 40 of the respondents or 25 percent are "moderately aware" of the liability. And 22.5 percent or 36 of the respondents are "aware". Thus, 118 out of 160 sophomore students are informed of the liability attaches to participants to hazing. Question number 3 provides for 
Table 6. Knowledge of the Potential Liability Provided under RA 8049.

\begin{tabular}{|c|c|c|c|c|c|c|c|c|c|c|c|c|c|}
\hline IV. Offenders in Case of Violation & $\mathrm{f}$ & $\mathrm{TF}$ & f & $\mathrm{TF}$ & f & $\mathrm{TF}$ & f & $\mathrm{TF}$ & $\mathrm{f}$ & $\mathrm{TF}$ & WTF & WM & $\mathrm{VD}$ \\
\hline $\begin{array}{l}\text { 1) School representatives must be present } \\
\text { during initiation rites(section } 3 \text { ) }\end{array}$ & 22 & 110 & 37 & 148 & 54 & 162 & 21 & 42 & 32 & 32 & 492 & 3.07 & Aware \\
\hline $\begin{array}{l}\text { 2) Officers and members of the organization } \\
\text { who are present during hazing are } \\
\text { considered as principals. (section } 4 \text { ) }\end{array}$ & 44 & 220 & 40 & 160 & 37 & 111 & 22 & 44 & 23 & 23 & 558 & 3.48 & $\begin{array}{c}\text { Moderately } \\
\text { Aware }\end{array}$ \\
\hline $\begin{array}{l}\text { 3) In case death occurs, the owner of the } \\
\text { place is charged together with the members } \\
\text { of the group(section } 4)\end{array}$ & 41 & 205 & 46 & 184 & 33 & 99 & 22 & 44 & 24 & 24 & 556 & 3.47 & $\begin{array}{l}\text { Moderately } \\
\text { aware }\end{array}$ \\
\hline $\begin{array}{l}\text { 4) RA } 8049 \text { penalizes faculty members who } \\
\text { consented to hazing. }\end{array}$ & 42 & 210 & 34 & 136 & 36 & 108 & 31 & 62 & 23 & 23 & 539 & 3.36 & Aware \\
\hline $\begin{array}{l}\text { 5) Alumni members of the organization } \\
\text { who helped plan the activity i shall be held } \\
\text { liable. }\end{array}$ & 32 & 160 & 32 & 128 & 54 & 162 & 30 & 60 & 18 & 18 & 528 & 3.3 & Aware \\
\hline $\begin{array}{l}\text { 6) The former officers or alumni of the } \\
\text { organization, who but not present in the } \\
\text { activity is charged as principals. }\end{array}$ & 24 & 120 & 29 & 116 & 64 & 192 & 26 & 52 & 23 & 23 & 503 & 3.14 & Aware \\
\hline $\begin{array}{l}\text { 7) Any person present in the place where } \\
\text { hazing takes place is a prima facie evidence } \\
\text { of his participation (section } 4 \text { ) }\end{array}$ & 36 & 180 & 42 & 168 & 39 & 117 & 20 & 40 & 29 & 29 & 534 & 3.3 & Aware \\
\hline $\begin{array}{l}\text { 8) The institutions involved in } \\
\text { preventing hazing should also take an active } \\
\text { role in educating the youth and in dispelling } \\
\text { the tradition of violence. }\end{array}$ & 34 & 170 & 43 & 172 & 36 & 108 & 18 & 36 & 20 & 20 & 506 & 3.16 & Aware \\
\hline $\begin{array}{l}\text { 9) In case hazing is committed by a minor, } \\
\text { his parents shall be liable instead. }\end{array}$ & 25 & 125 & 39 & 156 & 40 & 120 & 28 & 56 & 30 & 30 & 489 & 3.05 & Aware \\
\hline
\end{tabular}

liability of the owner of the place where hazing is held. 48 or 30 percent of the respondents are "moderately aware" of the possible liability of the owner of the place. On the other hand, $40 \%$ or $25 \%$ percent of the respondents are fully aware of the liability of the owner of the place. Finally, 31 or 19.3 percent of the respondents are "aware" of the liability of the owner of the place as principal.

On question number 6, 62 or 38.75 percent of the respondents are "aware" of the liability of persons who planned the hazing activity. $47 \%$ or $29.37 \%$ percent are not aware of the potential liability of a person who planned but not present during hazing. 51 or 31 percent are "aware”. All in all, 69.75 percent are aware that there is liability attached to the person who planned the event.

Question number 8 elicits respondents' awareness on the institutional responsibility of resolving the problem of hazing. Accordingly, sophomore students' believe that social institutions should be responsible of preventing hazing by educating the youth and dispelling violence on campus. 34 of the respondents or 21.25 percent are "fully aware" that hazing prevention is an institutional duty. Thus, the university should take an active role in hazing prevention. 42 of the respondents or 26.25 percent are "moderately aware" of such institutional obli- 
gation while $39 \%$ or $34.3 \%$ are "aware" of the university's duty to prevent hazing. Therefore, a total of 115 respondents or 71.87 percent out of 160 sophomore students are of the belief that the duty to take the bold step to stop hazing must come from social institutions. The family, school, government and community must take an active role in the campaign against campus violence. Among 160 sophomore students, 138 of them believe that an anti hazing campaign is necessary to solve the problem. A weighted average of 3.33 on Knowledge of Liabilities is arrived at and is verbally described as" moderately aware".

\subsection{Summary, Conclusion and Recommendation}

The study showed that sophomore students possess average and above average level of awareness on the hazing. They are "moderately aware" on the general concept of hazing and liabilities attached for violation while "aware" on the procedural requirements of RA 8049. They consider hazing as a practice only of Greek letter organization. They relate the concept of hazing to fraternity activity and infliction of physical harm upon person of an applicant. A low level of understanding could relate to other aspect of hazing to wit; psychological and social humiliation. On the issue of hazing and acceptability by reason of tradition, the findings tend to show that respondents accept hazing as a practice. They also believe that to prohibit Greek letter societies is a way to prevent hazing.

The study also showed that the sophomore student leaders have above average level of awareness on the contents of RA8049. Nevertheless, some highlights of the findings require special attention. The respondents' exclusive interpretation of the coverage of RA 8049 to physical harm may expose them from undue charges of violating RA 8049. They must remember that social and psychological sufferings are also covered by law. Associating hazing with Greek society is a misplaced logic. Other student organizations are also committing hazing e.g. sports team, social organization, citizens' military training and like are also guilty of hazing provided the same is set as a prerequisite for membership. The perception that hazing is acceptable because it is a part of student organization tradition and infliction of harm to new comers is acceptable as a test of determination provided a "calculated harm" is inflicted upon applicant is a dangerous presumption. The law and the approval of the university to extend the duration of initiation ritual is not supported by legal basis. Acceptability of physical violence as part of organizational ritual is likewise no legal foundation to stand on. The findings also showed that participants to hazing and the owner of the place are also liable.

\section{Recommendations}

1) Massive reorientation must be done to impart the knowledge that hazing comes in many forms including social and psychological harm. The Student Council officers may sponsor the same.

2) That violence is not a measure of applicant's willingness to serve the organ- 
ization. The members of the student organizations must embrace the noble objectives of the group. This may be done by student affairs professionals.

3) A discussion on Hazing may be included in the collegiate level curriculum and student organizations may be required to undergo anti hazing seminar before they may be allowed to operate aboveground.

4) It is the duty of social institutions like the university to stop hazing by creating a multi-sectoral task force who will look into the case of hazing in the university. Participation may be solicited from family to law enforcement agencies.

5) In the case of institutions where cases of hazing are commonly committed during initiation ritual, a restorative justice based upon principles of organizational learning may make a difference. Avoiding the legal implication by dissolving Greek societies cannot solve the problem.

Every school year new list of victims comes out in the news. Hazing remains the number one agent of violence in higher education campuses in the Philippines. It is not because it is tolerated. It is in fact, avoided by many school authorities by imposing moratorium on recognition of Greek letter societies thereby compelling them to operate underground along with the perception of the respondents, that hazing remains a tradition in many student organizations. Under the circumstance, one may ask, what has the law got to do with it?

\section{References}

[1] Merriam Webster. https://www.merriam-webster.com/

[2] Mercuro, A., Meritt, S. and Fiumefreddo, A. (2014) The Effects of Hazing on Student Self-Esteem: Study of Hazing Practices in Greek Organizations in a State College. The Ramapo Journal of Law and Society, 59-86. https://www.ramapo.edu/law-journal/files/2014/03/the-effects-of-hazing.pdf

[3] Cimino, A. (2011) The Evolution of Hazing: Motivational Mechanisms and the Abuse of Newcomers. Journal of Cognition and Culture, 11, 241-267.

http://www.aldocimino.com/cimino_2011.pdf https://doi.org/10.1163/156853711X591242

[4] Asel, M., Seifert, T. and Pascarella, E. (2009) The Effects of Fraternity Membership on College Experiences and Outcomes: A Portrait of Complexity Oracle. The Research Journal of the Association of Fraternityl Sorority Advisors, 4, Issue 2.

[5] Barber, J. (2012) Ever After Strictly and Rigidly Obeyed with Some Exceptions Administrative Responses to Hazing in the 1870 s https://www.academia.edu/5882893/

[6] Campo, S., Poulos, G. and Sipple, J. (2005) Prevalence and Profiling: Hazing among College Students and Points of Intervention. American Journal of Health Behavior, 29, 137.

[7] Sterner, R. (2008) The History of Hazing in American Higher Education. https://ruthsterner.files.wordpress.com/2008/05/histpdf.pdf

[8] Gabriel, A.G. and Mangahas, T.L. (2016) Revisiting the Anti-Hazing Law in Selected Higher Education Institutions in Nueva Ecija, Philippines: A Policy Review. Open Access Library Journal, 3, e3177. http://dx.doi.org/10.4236/oalib.11031

[9] Allan, E.J. and Madden, M. (2008) Hazing in View: College Students at Risk. http://www.stophazing.org/wp-content/uploads/2014/06/hazing_in_view_web1.pdf 
[10] Siripakpian, P. (2015) Attitudes of Administrators towards Student Hazing in Ubonratchathani University in Thailand.

http://www.academia.edu/.../Attitudes_of_Administrators_towards_Student_Hazin g_inUbo

[11] Arnold, W. (2005) A Comparison of Hazing Attitudes in Student Affairs Professionals at Selected Historically Black Learning Institutions of Higher Education in Tennessee University.

[12] Nachura, A. (2006) Outline Reviewer in Political Law. VJ Graphic Arts, Inc., Quezon.

[13] (2004) Professional Regulatory Commission v. De Guzman, G.R. No. 144681.

[14] RA 8049 An Act regulating Hazing and Other Forms of Initiation Rites in Fraternities Sororities and Other Student Organizations and Providing Penalties Therefor. Official Gazette of the Republic of the Philippines. http://www.gov.ph/1995/07/06/republic-act-no-8092

[15] The 1987 Philippine Constitution. Congress of the Philippines. Batasan Road. Philippines.

[16] De Leon, H.S. (2002) Textbook On The Philippine Constitution. https://www.goodreads.com/book/show/12395398-textbook-on-the-philippine-con stitution

[17] Albano, E.S. (2000) Bar Review Guide in Civil Law. Rex Bookstore. Manila.

[18] Amadoravs Court of Appeals April 15, 1988.

[19] SUPREME COURT of the Philippines G.R. No. L-29025 October 4, 1971.

[20] Gonzales, A. and Diaz, V. (2004) Laws on Education and the Private School Administration. Phoenix Publishing House, Quezon City.

[21] Perkins, A. and Zimerman, D. (2011) Changing Trends in the Undergraduate Fraternity/Sorority Experiences: An Evaluative and Analytical Literature Review. Oracle, 6, 57-73.

[22] Gabriel, A.G. (2012) The Implementation of the Anti hazing Law: Responses of Student Affairs Professionals and Student Organization Members. Rurban Science and Technology Journal, 111, 132-139.

[23] American Association State Colleges and University Annual Report (2005). http://www.aascu.org

[24] Diola, C. (2014) Hazing Deaths in the Philippines: A Recent History. http://www.philstar.com/news-feature/2014/07/10/1344288/hazing-deaths-philippi nes-recent-history

[25] Alcedo, J., Cabacang, A., Empig, C., Peralta, J. and Puno, R. (2015) Buhay Frat: The Lived Experiences of the Fraternity Hazing Initiators in Palawan Philippines. University Psychology Society. Palawan State University.

[26] Gamboa, M. (2002) An Introduction to Philippine Law. Central Lawbook Publishing Co., Inc., Manila.

[27] Zacharda, C.S. (2009) How Peer Leadership Impacts Hazing in the Arena of Non Revenue Income Generating College Athletics. Unpublished Masters Degree Thesis, Rossier. 